\title{
The Selective Use of a Diverting Stoma in Rectal Surgery
}

\author{
Daitlin E. Huisman ${ }^{1}$ - Erik W. Ingwersen ${ }^{1}$ - Muriël Reudink ${ }^{3} \cdot$ Boukje T. Bootsma $^{1}$ - Gerrit D. Slooter ${ }^{3}$. \\ Jan Willem T. Dekker ${ }^{2} \cdot$ Freek Daams $^{1}$
}

Received: 27 August 2021 / Accepted: 30 December 2021 / Published online: 1 February 2022

(c) The Author(s) 2022

Keywords Anastomotic leakage · BMI Body mass index · ASA American Society of Anesthesiologists · TNM Tumour node metastasis $\cdot$ AJCC American Joint Committee on Cancer $\cdot$ AV Anal verge $\cdot$ MAP Mean arterial pressure

\section{Introduction}

A diverting stoma is recommended by some as a routine procedure to lower incidence of $\mathrm{AL}$ and mitigate its consequences. Others, however, state that the diverting stoma is overused, as they describe no differences in AL rate between patients with and without a diverting stoma. ${ }^{1}$ Next to this, many patients experience stoma-related morbidity such as skin irritation, dehydration, stoma site complications, psychological distress, and reversal surgery with potential complications. Ultimately, many patients never undergo a reversal of their diverting stoma. ${ }^{2}$ Between 2007 and 2019, $89 \%$ of the patients who underwent rectal cancer surgery in Australia or New Zealand received a diverting stoma. ${ }^{3}$ In the Netherlands, however, the incidence of a diverting stoma in rectal surgery is considerably low (40\% in 2016) and reduced in the last decade. ${ }^{4}$ The relatively low application rate is possibly due to a selection of patients. This study was designed to identify patient characteristics and intraoperative conditions related to the presence of a diverting stoma and the impact on anastomotic leakage.

Daitlin E. Huisman

d.huisman@amsterdamumc.nl

1 Department of Surgery, Amsterdam University Medical Centers, Location VUmc, Amsterdam, The Netherlands

2 Department of Surgery, Reinier de Graaf Gasthuis, Delft, The Netherlands

3 Department of Surgery, Máxima Medical Center Veldhoven, Veldhoven, The Netherlands

\section{Method}

The data were used of a prospective, observational study from January 2016 to December 2019 from fourteen hospitals in four countries. This study was an additional subanalysis of the LekCheck study. ${ }^{5}$ All patients undergoing rectum resection with primary anastomosis were included.

\section{Results}

A total of 351 patients were included for this sub-study. A diverting stoma was created in 97 patients $(27.6 \%)$. The following seven variables were associated with a diverting stoma in univariate analysis: smoking status, neoadjuvant therapy, American Joint Committee on Cancer stage, tumor distance, fluid administration, blood loss, and an intraoperative event. In the multivariate analysis, the following variables were independently associated with a diverting stoma: tumor distance $(p<0.001)$, neoadjuvant therapy $(p<0.001)$, blood loss $(p=0.003)$, fluid administration $(p=0.003)$, and an intraoperative event $(p=0.022)$. Anastomotic leakage occurred in nine patients $(9.3 \%)$ with a diverting stoma and in 34 patients $(13.4 \%)$ without $(p=0.297)$. In patients with anastomotic leakage, fewer interventions were necessary when a diverting stoma was constructed $(p=0.001)$ (Tables 1, 2, and 3).

\section{Discussion}

This study found that the following factors were independently associated with a diverting stoma: tumor distance, neoadjuvant therapy, blood loss during surgery, fluid administration, and an intraoperative event. The use of a diverting 


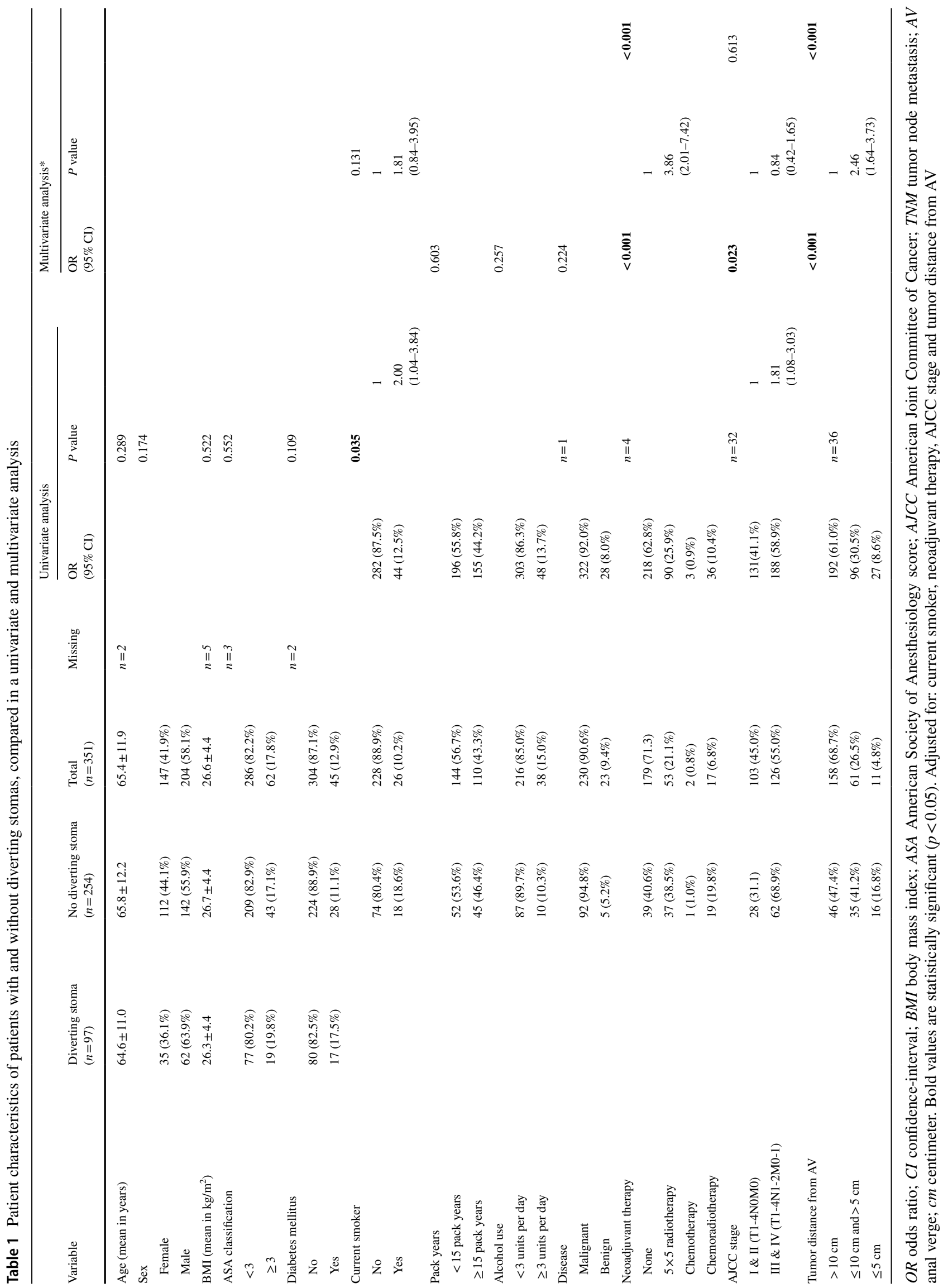


Table 2 Intraoperative factors of patients with and without diverting stomas, compared in a univariate and multivariate analysis

\begin{tabular}{|c|c|c|c|c|c|c|c|c|}
\hline \multirow[b]{2}{*}{ Variable } & \multirow[b]{2}{*}{$\begin{array}{l}\text { Diverting stoma } \\
(n=97)\end{array}$} & \multirow[b]{2}{*}{$\begin{array}{l}\text { No diverting stoma } \\
(n=254)\end{array}$} & \multirow[b]{2}{*}{ Total $(n=351)$} & \multirow[b]{2}{*}{ Missing } & \multicolumn{2}{|c|}{ Univariate analysis } & \multicolumn{2}{|c|}{$\begin{array}{l}\text { Multivariate analy- } \\
\text { sis* }\end{array}$} \\
\hline & & & & & $\begin{array}{l}\text { OR } \\
(95 \% \mathrm{CI})\end{array}$ & $P$ value & $\begin{array}{l}\text { OR } \\
(95 \% \mathrm{CI})\end{array}$ & $P$ value \\
\hline Use of vasopressor & & & & & & 0.555 & & \\
\hline No & $67(69.1 \%)$ & $167(65.7 \%)$ & $234(66.7 \%)$ & & & & & \\
\hline Yes & $30(30.9 \%)$ & $87(34.3 \%)$ & $117(33.3 \%)$ & & & & & \\
\hline Epidural use & & & & $n=11$ & & 0.337 & & \\
\hline No & $55(59.1 \%)$ & $160(64.8 \%)$ & $215(63.2 \%)$ & & & & & \\
\hline Yes & $38(40.9 \%)$ & $87(35.2 \%)$ & $125(36.8 \%)$ & & & & & \\
\hline Hemoglobin & & & & & & 0.363 & & \\
\hline $\begin{array}{l}<6.0 \mathrm{mmol} / \mathrm{L} \text { female } \\
\text { or }<6.5 \mathrm{mmol} / \mathrm{L} \text { male }\end{array}$ & $3(3.1 \%)$ & $4(1.6 \%)$ & $7(2.0 \%)$ & & & & & \\
\hline $\begin{array}{l}\geq 6.0 \mathrm{mmol} / \mathrm{L} \text { female } \\
\text { or } \geq 6.5 \mathrm{mmol} / \mathrm{L} \mathrm{male}\end{array}$ & $94(96.9 \%)$ & $250(98.4 \%)$ & $344(98.0 \%)$ & & & & & \\
\hline Fluid administration & & & & & & $<0.001$ & & 0.003 \\
\hline$<1000 \mathrm{~mL}$ & $20(20.6 \%)$ & $104(40.9 \%)$ & $124(35.3 \%)$ & & 1 & & 1 & \\
\hline$\geq 1000 \mathrm{~mL}$ & $77(79.4 \%)$ & $150(59.1 \%)$ & $227(64.7 \%)$ & & $\begin{array}{l}2.67 \\
(1.54-4.64)\end{array}$ & & $\begin{array}{l}2.50 \\
(1.37-4.57)\end{array}$ & \\
\hline Blood loss & & & & & & $<0.001$ & & 0.003 \\
\hline$<100 \mathrm{~mL}$ & $28(28.9 \%)$ & $140(55.1 \%)$ & $168(47.9 \%)$ & & 1 & & 1 & \\
\hline$\geq 100 \mathrm{~mL}$ & $69(71.1 \%)$ & $114(44.9 \%)$ & $183(52.1 \%)$ & & $\begin{array}{l}3.03 \\
(1.83-5.01)\end{array}$ & & $\begin{array}{l}2.34 \\
(1.34-4.01)\end{array}$ & \\
\hline Intraoperative event & & & & $n=6$ & & 0.001 & & 0.022 \\
\hline No & $78(80.4 \%)$ & $229(92.3 \%)$ & $307(89.0 \%)$ & & 1 & & 1 & \\
\hline Yes & $19(19.6 \%)$ & $19(7.7 \%)$ & $38(11.0 \%)$ & & $\begin{array}{l}2.94 \\
(1.48-5.83)\end{array}$ & & $\begin{array}{l}2.410 \\
(1.13-5.13)\end{array}$ & \\
\hline Approach & & & & & & 0.797 & & \\
\hline Open & $9(9.3 \%)$ & $18(7.3 \%)$ & $27(7.8 \%)$ & $n=6$ & & & & \\
\hline Laparoscopy & $84(86.6 \%)$ & $218(87.9 \%)$ & $302(87.5 \%)$ & & & & & \\
\hline $\begin{array}{l}\text { Laparoscopy with conver- } \\
\text { sion }\end{array}$ & $4(4.1 \%)$ & $12(4.8 \%)$ & $16(4.6 \%)$ & & & & & \\
\hline
\end{tabular}

OR odds ratio; $C I$ confidence-interval; $M A P$ mean arterial pressure. Bold values are statistically significant $(p<0.05)$. Adjusted for: current smoker, neoadjuvant therapy, AJCC stage and tumor distance from AV

Table 3 Patients with and without a diverting stoma and occurrence of anastomotic leakage, days until leakage was detected and severity. Reinterventions were scored when Clavien-Dindo was grade 3 or higher

\begin{tabular}{|c|c|c|c|c|}
\hline & $\begin{array}{l}\text { Diverting stoma } \\
\text { and AL }(n=9)\end{array}$ & $\begin{array}{l}\text { No diverting stoma } \\
\text { and } \operatorname{AL}(n=34)\end{array}$ & Missing & $P$ value \\
\hline Anastomotic leakage & 9 & 34 & & $0.297 *$ \\
\hline Days until anastomotic leakage was detected & & & $n=5$ & \\
\hline$<7$ days & $4(57.1 \%)$ & $24(77.4 \%)$ & & $0.257^{\wedge}$ \\
\hline$\geq 7$ days & $3(42.9 \%)$ & $7(22.6 \%)$ & & \\
\hline Reintervention needed & & & & $0.046^{\wedge}$ \\
\hline Yes & $5(55.6 \%)$ & $30(88.2 \%)$ & & \\
\hline No & $4(44.4 \%)$ & $4(11.8 \%)$ & & \\
\hline Death within 30 days postoperatively & & & & $0.370^{\wedge}$ \\
\hline Yes & $1(11.1 \%)$ & $1(2.9 \%)$ & & \\
\hline No & $8(88.9 \%)$ & $33(97.1 \%)$ & & \\
\hline
\end{tabular}

$A L$ anastomotic leakage. ${ }^{*} X^{2}$ test. ^Fisher's exact test

Entries in boldface is due to the signifance $p$ value 
stoma in this study was relatively low (27.6\%) and although the anastomotic leak rate was lower in patients with a diversion, this difference was not statistically significant. Other authors found that selective use of diverting stomas led to the same incidence of AL compared to policies in which diverting stoma was more routinely used. ${ }^{6}$ Proper application of selective use would drastically lower the burden of the stoma, preventing stoma-related complications (e.g., parastomal hernias, dehydration, stoma prolapse), discomfort, and costs, for many patients. On the other hand, it can potentially reduce complications in patients who are at high risk for AL, since fewer reinterventions were necessary for patients with $\mathrm{AL}$ and a diverting stoma.

\section{Conclusion}

The study showed differences in patient characteristics and intraoperative variables in patients with and without a diverting stoma. A diverting stoma showed a protective effect as the impact of AL was less severe, resulting in fewer reinterventions. Selective use is therefore suggested, since it prevents unnecessary application while protecting patients. The current focus should be on techniques to identify patients with increased risk as soon as the rectum resection, in order to apply the protective stoma restrictively in patients at risk.

Open Access This article is licensed under a Creative Commons Attribution 4.0 International License, which permits use, sharing, adaptation, distribution and reproduction in any medium or format, as long as you give appropriate credit to the original author(s) and the source, provide a link to the Creative Commons licence, and indicate if changes were made. The images or other third party material in this article are included in the article's Creative Commons licence, unless indicated otherwise in a credit line to the material. If material is not included in the article's Creative Commons licence and your intended use is not permitted by statutory regulation or exceeds the permitted use, you will need to obtain permission directly from the copyright holder. To view a copy of this licence, visit http://creativecommons.org/licenses/by/4.0/.

\section{References}

1. Nurkin S, Kakarla VR, Ruiz DE, Cance WG, Tiszenkel HI. The role of faecal diversion in low rectal cancer: a review of 1791 patients having rectal resection with anastomosis for cancer, with and without a proximal stoma. Colorectal disease : the official journal of the Association of Coloproctology of Great Britain and Ireland. 2013;15(6):e309-16.

2. Emmanuel A, Chohda E, Lapa C, Miles A, Haji A, Ellul J. Defunctioning Stomas Result in Significantly More Short-Term Complications Following Low Anterior Resection for Rectal Cancer. World J Surg. 2018;42(11):3755-64.

3. Grupa VEM, Kroon HM, Ozmen I, Bedrikovetski S, Dudi-Venkata NN, Hunter RA, et al. Current practice in Australia and New Zealand for defunctioning ileostomy after rectal cancer surgery with anastomosis: Analysis of the Binational Colorectal Cancer Audit. Colorectal disease : the official journal of the Association of Coloproctology of Great Britain and Ireland. 2021;23(6):1421-33.

4. de Neree Tot Babberich MPM, Detering R, Dekker JWT, Elferink MA, Tollenaar R, Wouters M, et al. Achievements in colorectal cancer care during 8 years of auditing in The Netherlands. European journal of surgical oncology : the journal of the European Society of Surgical Oncology and the British Association of Surgical Oncology. 2018;44(9):1361-70.

5. Huisman DE, Reudink M, van Rooijen SJ, Bootsma BT, van de Brug T, Stens J, et al. LekCheck: A Prospective Study to Identify Perioperative Modifiable Risk Factors for Anastomotic Leakage in Colorectal Surgery. Annals of surgery. 2020.

6. Snijders HS, van Leersum NJ, Henneman D, de Vries AC, Tollenaar RA, Stiggelbout AM, et al. Optimal Treatment Strategy in Rectal Cancer Surgery: Should We Be Cowboys or Chickens? Annals of surgical oncology. 2015;22(11):3582-9.

Publisher's Note Springer Nature remains neutral with regard to jurisdictional claims in published maps and institutional affiliations. 